\title{
Quality assessment and hydrogeochemical characteristics of groundwater in Kerzaz and Beni Abbes along Saoura valley, southwest of Algeria
}

\author{
Youcef Benmoussa $^{1} \cdot$ Boualem Remini $^{2} \cdot$ Mohamed Remaoun $^{1}$
}

Received: 31 October 2019 / Accepted: 11 June 2020 / Published online: 24 June 2020

(c) The Author(s) 2020

\begin{abstract}
The present study focused on the hydrochemistry of groundwater in Kerzaz and Beni Abbes in Saoura oases (southwest of Algeria) to assess the quality of groundwater for determining its suitability for drinking and irrigation purposes. The study area experiences a hyper-arid climate characterized by low rainfall $50-100 \mathrm{~mm} /$ year and excessive drought. Groundwater samples were collected from 24 locations to ensure a good spatial distribution to cover all the study areas. Standards laboratory methods were used to determine physicochemical groundwater properties. The result for this study showed that the water was to be found unsuitable for drinking purposes except for few samples in Kerzaz and Beni Abbes. Except for PI values, all other physicochemical parameters (EC, SAR, MAR), and according to the US salinity diagram, groundwater in Kerzaz was to be found satisfactory for irrigation especially if the soil permeability is improved and the leaching is guaranteed by applying extra frequently irrigation. In Beni Abbes, 58.33\% of water samples show that water can be used if rapid permeability is guaranteed, which is the case in Beni Abbes soils, and 25\% present medium salinity and low to medium alkalinity (C2S1, C2S2, C3S3) and only the natural spring presents a low salinity and low alkalinity C1S1 permitting the use of water for irrigation with most crops on most soil. Piper diagram indicates groundwater in Kerzaz belongs to $\mathrm{CaCl}$ type, while in Beni Abbes four types were recognized, $\mathrm{NaCl}, \mathrm{CaMgHCO}_{3}, \mathrm{CaCl}$ and mixed $\mathrm{CaCl}$ type with $16.66 \%, 8.33 \%, 41.66 \%$ and $33.33 \%$, respectively.
\end{abstract}

Keywords Kerzaz $\cdot$ Beni Abbes $\cdot$ Groundwater quality $\cdot$ Physicochemical parameters $\cdot$ Piper diagram $\cdot$ Drinking and irrigation suitability $\cdot$ Hydrogeochemistry

\section{Introduction}

While groundwater is the largest reserve of liquid freshwater in the world (about 8-11 million $\mathrm{km}^{3}$ ), few studies have sought to quantify the evolution of this precious underground reservoir and to identify its quality to preserve it (Margat 1990; Remini 2016). Groundwater is the main source of supply for the inhabitants of Saoura oases.Since the early 1970s, Algeria has built on the wadi Guir the large

Youcef Benmoussa

youcefbenkadi@gmail.com

1 Department of Hydraulics, Faculty of Civil Engineering and Architecture, University Hassiba Benbouali of Chlef, Chlef, Algeria

2 Department of Water Sciences and Environment, Faculty of Technology, The University of Blida, Blida, Algeria dam of Djorf Torba with a capacity of 360 million $\mathrm{m}^{3}$ for the irrigation of the plain of Abadla with an area of 5400 ha (Kabour et al. 2016). The construction of large equipment like that on Oued Guir disturbed the ecosystem of the region since it drains more than $80 \%$ of the total flow of the wadi Saoura and $20 \%$ of the flow comes from the wadi Zouzfana. This new situation has led to an appreciable decrease in shallow flows in Oued Saoura and consequently a reduction of the water table and a deterioration of its quality accelerated by excessive pumping and population growth translated into increased consumption of water. Several studies on water quality have been carried out in the Saoura region before and after the construction of the Djorf Torba dam (Dubief 1955; Merzougui 2011; Rezzoug et al. 2017). A comparison of these studies reveals that groundwater in Saoura oases is facing water quality issues. It is in this context that this study aims to assess the quality of the groundwater both of low and high Saoura oasis, respectively, in Beni Abbes and Kerzaz 
and to explain the phenomena at the origin of the mineralization of these waters. The collected data were compared with Algerian, WHO and FAO standards to determine if this water was suitable for drinking and irrigation purposes.

\section{Study area}

The oases of Saoura located in the southwest of Algeria admit $26^{\circ} 30^{\prime}$ north latitude and $1^{\circ} 29^{\prime}$ west longitude, considered as green islands dispersed in a vast ocean of dunes which represent the western part of the Algerian Sahara, spread over about $789,000 \mathrm{~km}^{2}$. From the region of Ighli in the upstream, an important stream named wadi Saoura is born and which is the result of the confluence (fusion) of two streams: wadi Guir (on the high Moroccan atlas) and wadi Zouzfana ( on the mountains of ksours between Figuig and Beni Ounif) (Hadidi et al. 2018). The Oued Saoura continues to flow on the surface over a length of $600 \mathrm{~km}$ and at each place where the natural conditions are favorable appear a series of oases which are from north to south: Igli, Beni Abbes, El Ouata, Kerzaz, Timoudi, Ouled Khoder, Elksabi.

Saoura region experiences a hyper-arid climate characterized by low rainfall $50-100 \mathrm{~mm}$ of rain per year (Rezzoug et al. 2017) and excessive drought. With a clear sky, almost without clouds, the region of Saoura is above all "the country of the sun" (Fig. 1).

\section{Methodology}

A series of two sampling campaigns were carried out during December 2017 and April 2018 in Beni Abbes and Kerzaz to collect 24 samples ( 21 open wells, 2 boreholes and 1 natural spring) using a $1 \mathrm{~L}$ sampler. The sampling sites were carefully selected to ensure a good spatial distribution in the oases. Water samples collected in polyethylene bottles of $1 \mathrm{~L}$ capacity are stored in the dark and cool with the aid of a refrigerator. All the physicochemical analyses were performed following standards methods (APHA 1998; Rodier et al. 2009). Temperature T, hydrogen potential $\mathrm{pH}$, electrical conductivity $\mathrm{EC}$ and turbidity NTU are the physical parameters measured on-site using a multi-parameter meter (Horiba U10). Calcium Ca, magnesium $\mathrm{Mg}$, potassium $\mathrm{K}$, sodium $\mathrm{Na}$ were determined by flame atomic absorption spectrometry. The concentration of chloride and sulfates was determined by the Mohr titration methods and the turbidimetric method, respectively; nitrate $\left(\mathrm{NO}_{3}\right)$ was determined by a spectrophotometric technique. Bicarbonate present in the water samples was calculated from the measured total alkalinity values which were determined by neutralization of a certain volume of water by a dilute mineral acid, in the presence of a colored indicator.

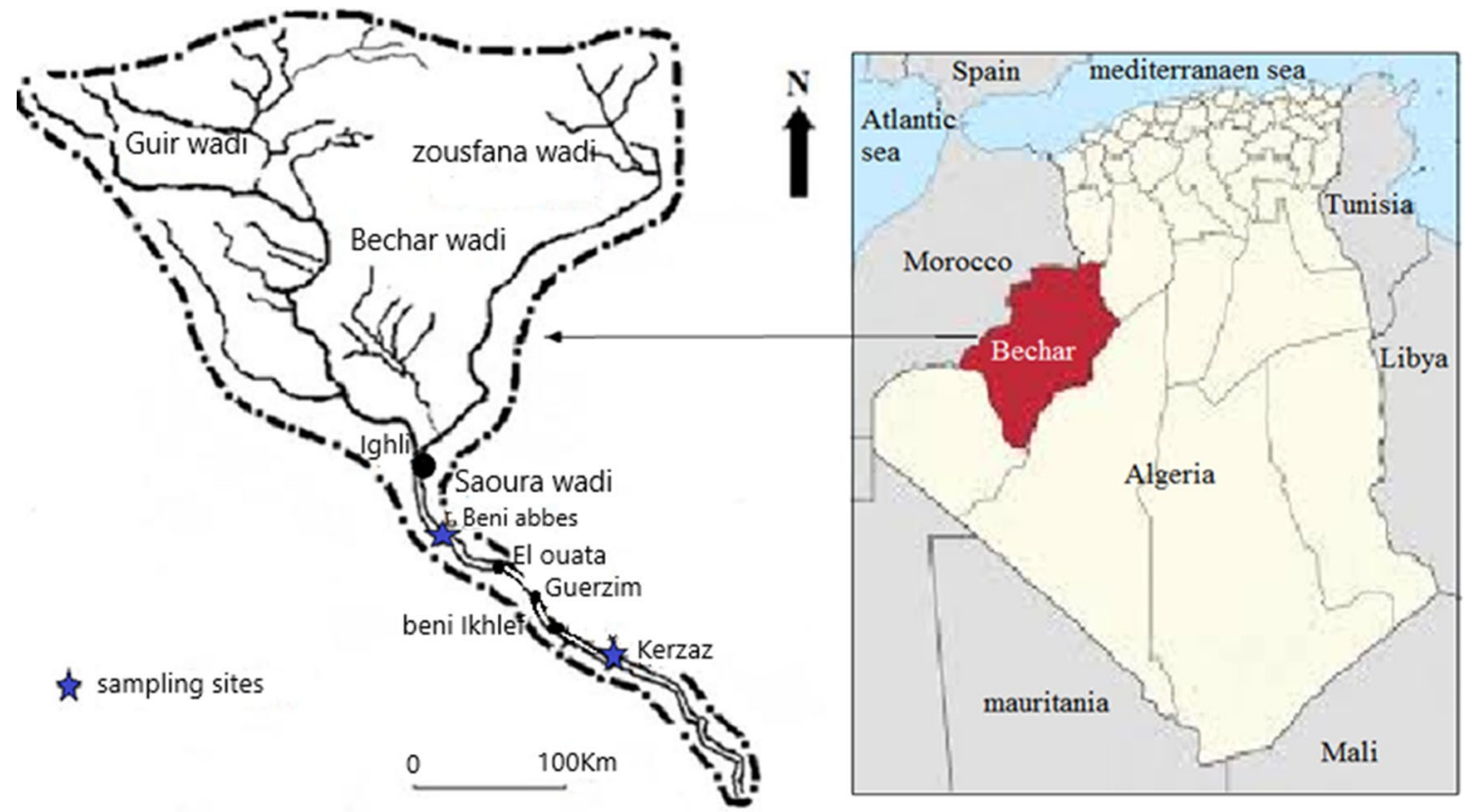

Fig. 1 Geographic locations of the study area 


\section{Results and discussion}

Physicochemical analysis of water from all studied wells and boreholes in Kerzaz and Beni Abbes is summarized in Tables 1 and 2.

The biological production of water is directly related to its temperature because it affects the physical and chemical properties of it; in particular, its density, its viscosity, the solubility of its gases (oxygen particularly) and the speed of chemical and biochemical reactions (Rice et al. 2017). The results obtained show that the temperature does not vary greatly from one well to another with a maximum of $26.5^{\circ} \mathrm{C}$ in the two oases and it was well within the safe limits of drinking water (Algerian standards).

The world health organization prescribed $\mathrm{pH}$ water of 6.5-8.5 for drinking purposes (WHO 2011). The $\mathrm{pH}$ value does not show a large variation from one well to another with a minimum of 7.11 at point $\mathrm{P} 9$ and a maximum of 8.3 at the natural spring in Beni Abbes oasis which reflects slight alkalinity of the waters due to bicarbonate. All $\mathrm{pH}$ values are within the prescribed limit for drinking water. The conductivity electric is the conductance of a water column between two metal electrodes; it allows evaluating the overall mineralization of water (Weast 1968; Rodier et al. 2009). For all the samples of Kerzaz and Beni Abbes, the conductivity is between 192 and $4450 \mu \mathrm{s} \mathrm{cm}^{-1}$. The waters closest to the western erg have lower conductivity values compared to those located near the wadi Saoura. This can be explained by an increase in dry residues due to the drying up of the wadi Saoura after the construction of the Djorf Torba dam in 1969, the uncontrolled evolution of the surface wells abandoned by the farmers and the phenomenon of evaporation led to a deterioration of the water quality reflected by high conductivity electric exceeding the international standard. Almost all samples cross the permissible limit of $600 \mu \mathrm{s} \mathrm{cm}^{-1}$ (WHO 2008) except P4, P5, P7 and the natural spring in Beni Abbes.

The total dissolved solids (TDS) values in Kerzaz and Beni Abbes oases vary from 541 to $845 \mathrm{mg} / \mathrm{L}$ and from 286 to $1087 \mathrm{mg} / \mathrm{L}$, respectively. In both oases, TDS increases from the Hamada slope in the east to the wadi Saoura in the west with a high value which exceeds the WHO limits (1000 mg/L) in Beni Abbes with $25 \%$ of samples. $75 \%$ and $25 \%$ of samples were within the acceptable limits set by WHO (WHO 2008) in Kerzaz and Beni Abbes, respectively. This can be explained by the dissolution of the salts contained in the quaternary formation sand, the evaporation in wells of large diameter and the rise of the waters of the infero-flux charged with salts by pumping and diffusion phenomenon.

The total hardness is mainly due to the dissolved salts of calcium and magnesium; their concentration too strong makes the water very hard. The hardness of natural water depends on the geological structure of the soils crossed; it is considered as an indicator of the level of limestone in the water (Amadou et al. 2014; Rice et al. 2017). Virtually all values of total hardness presented by wells and boreholes are found in the range of (267-661 mg/L) in Kerzaz and (141-936 mg/L) in Beni Abbes. Most of them are within the recommended limit set by WHO with less than $500 \mathrm{mg} / \mathrm{L}$ in Kerzaz, in contrast to Beni Abbes samples where almost all values are well above this limit with a maximum of $936 \mathrm{mg} / \mathrm{L}$. This can be explained by the lithological nature of quaternary limestone, and it is proportional to $\mathrm{Ca}$ and $\mathrm{Mg}$ contents in all wells and boreholes.

Calcium is a major component of water hardness and usually the dominant element of drinking water. Its content varies mainly according to the nature of the lands crossed. Calcium contents range from 267 to $650 \mathrm{mg} / \mathrm{L}$ in Kerzaz and from 73 to $667 \mathrm{mg} / \mathrm{L}$ in Beni Abbes oases. The WHO sets a maximum value of $50 \mathrm{mg} / \mathrm{L}$ as an allowable drinking water limit (WHO 2008). This value is largely exceeded by the waters of the alluvial aquifer. Calcium is due to the dissolution of calcium carbonate in the quaternary limestone in geological formations of the Saoura Valley (Merzougui 2011).

The magnesium ion is a significant element of water hardness; its content depends on the composition of the sedimentary rocks encountered (dolomitic limestone, Jurassic or Middle Triassic dolomites) (Sayad et al. 2017). More than half of the samples have a magnesium concentration higher than the standard recommended by WHO at $75 \mathrm{mg} / \mathrm{L}$ (WHO 2008) in both locations of Kerzaz and Beni Abbes. This can be explained by the exchange of ions between the water and the magnesium clay contained in the quaternary sands in the region Saoura Valley.

Sulfates result from runoff or infiltration into gypsum soils. They also result from the activity of certain bacteria (chlorothiobacteria, rhodothiobacteria, etc.). This activity can oxidize toxic hydrogen sulfide $\left(\mathrm{H}_{2} \mathrm{~S}\right)$ to sulfate (Oga et al. 2010). The sulfate contents vary between 84.5 and $2986.5 \mathrm{mg} / \mathrm{L}$ in Beni Abbes and 17-403 mg/L in Kerzaz exceeding the standard fixed by WHO $(250 \mathrm{mg} / \mathrm{L})$ (WHO 2011). This is due to leaching clays and marl present in the quaternary formation.

The natural origin of chloride in water is weathering of rock salts and atmospheric deposition of oceanic aerosols, while the anthropogenic sources include industrial or domestic sewage effluents and runoff from agricultural fields through fertilizers (Chattopadhyay et al. 2005). In general, chlorides present in drinking water do not have toxic consequences for humans even at high concentrations $(1000 \mathrm{mg} / \mathrm{L})$ but can be harmful to the taste of water by giving it a salty taste and an effective laxative, besides they promote the process of corrosion. More than half of

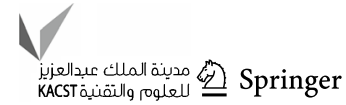




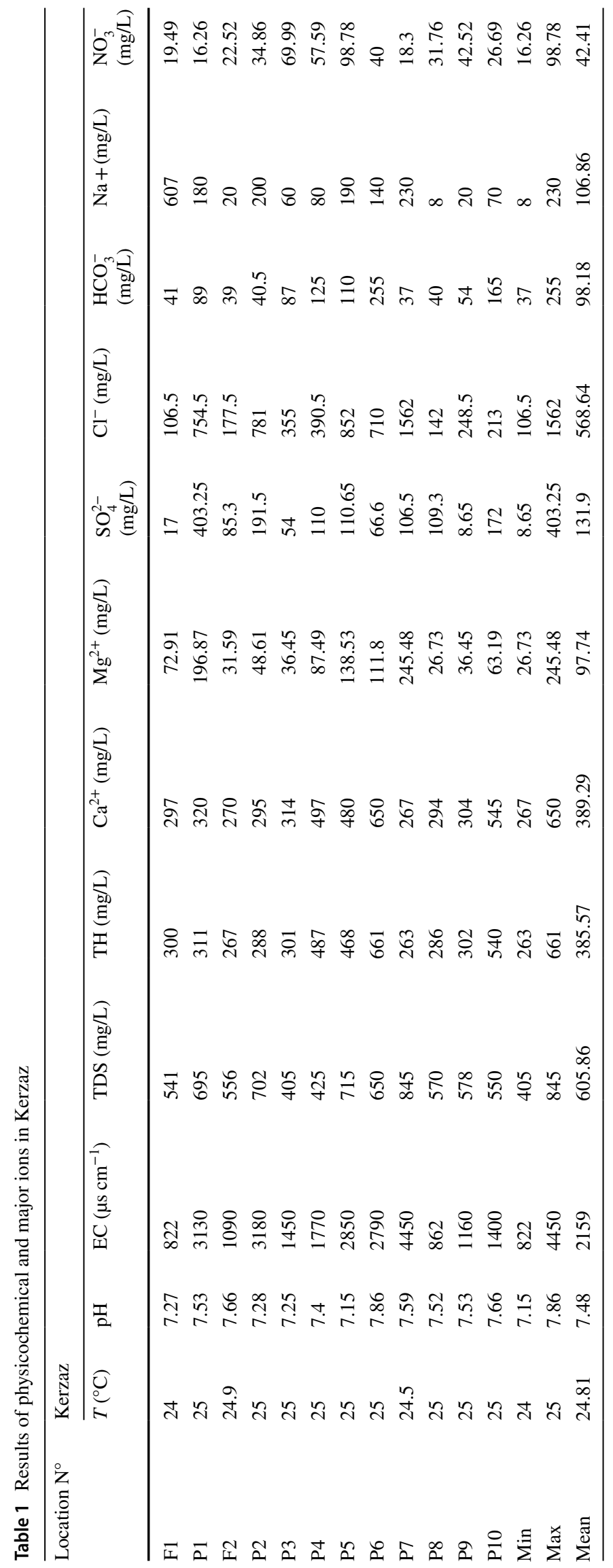




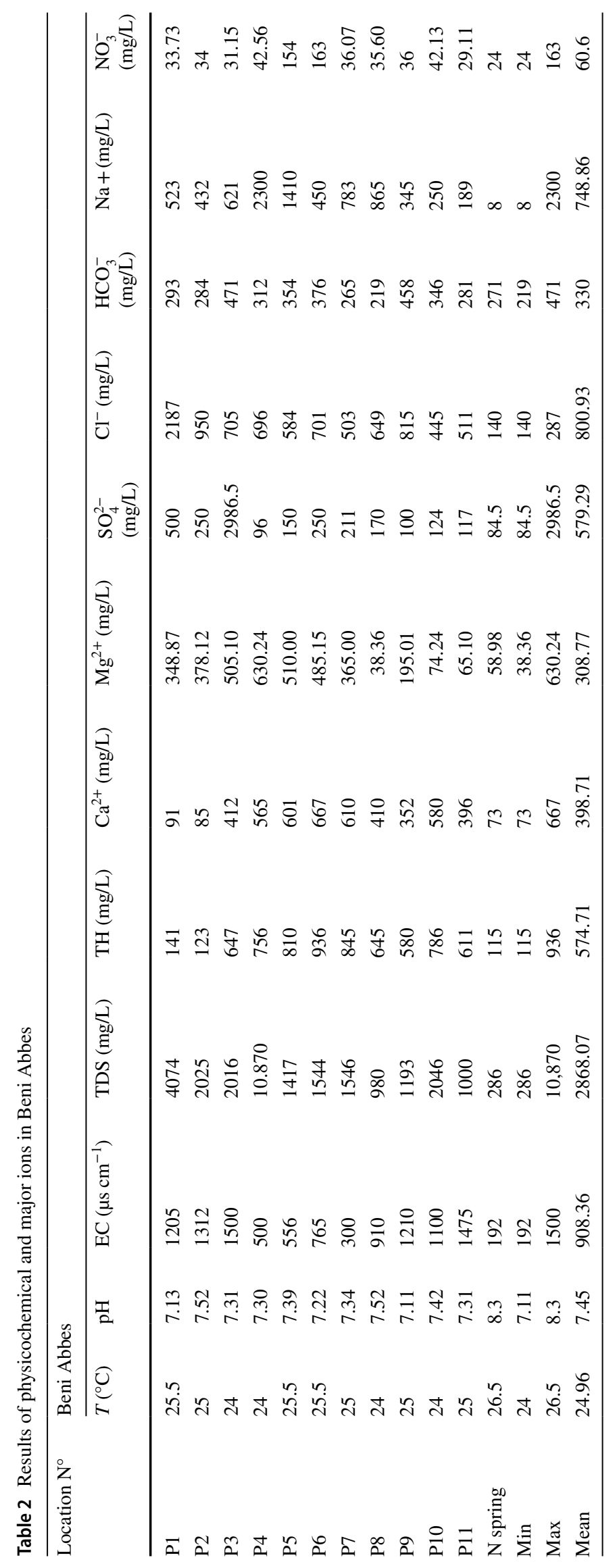


the samples have a chloride concentration higher than the standard recommended by WHO at $250 \mathrm{mg} / \mathrm{L}$ (WHO 2011); all values range from 106.5 to $1562 \mathrm{mg} / \mathrm{L}$ and from 140 to $2187 \mathrm{mg} / \mathrm{L}$ in Kerzaz and Beni Abbes, respectively. This can be explained by the fact that the chlorides have a geological origin linked to the leaching of the quaternary, clay and marly alluvial formations.

In natural waters, the alkalinity results most generally from the presence of hydrogen carbonates, carbonates and hydroxides. The bicarbonates come mainly from the dissolution of free $\mathrm{CO}_{2}$ in relatively high $\mathrm{pH}$ solutions. The bicarbonate content varies between 70 and $250 \mathrm{mg} / \mathrm{L}$ in Kerzaz and from 281 to $471 \mathrm{mg} / \mathrm{L}$ in Beni Abbes, so the results do not exceed the WHO standards of $500 \mathrm{mg} / \mathrm{L}$ (Lachache et al 2018).

The origin of sodium in water is not only the leaching of geological formations containing sodium chloride but also the decomposition of mineral salts such as sodium and aluminum silicates, marine fallout, saltwater in the aquifers and many industrial uses (Rodier et al. 2009). In Kerzaz region, the sodium contents vary between 8 and $230 \mathrm{mg} / \mathrm{L}$; all the water points analyzed have a concentration lower than the value set by the WHO at $200 \mathrm{mg} / \mathrm{L}$ (WHO 2011) except for the wells P7; However, in Beni Abbes, the sodium contents vary largely from 8 to $2300 \mathrm{mg} / \mathrm{L}$ exceeding the WHO standards in overall samples which can be explained by the leaching of clay formations of quaternary age by water and the rise of saline waters of the infero-flux caused by the overexploitation of the wells in this area by motor pumps.

Nitrates are naturally present in groundwater at low concentrations; however, significant levels in the water are an index of pollution of agricultural origin (fertilizer), urban or industrial; they can come from water by decomposition of organic matter or by leaching of soils crossed by water (Krishna Kumar et al. 2009). All the samples analyzed were within the acceptable limit of $50 \mathrm{mg} / \mathrm{L}$ set by WHO (WHO 2011) except for the wells P3, P4 and P5 in Kerzaz with a maximum of $98.78 \mathrm{mg} / \mathrm{L}$; P5 and P6 within Beni Abbes with a maximum of $60.6 \mathrm{mg} / \mathrm{L}$.

\section{Water quality for irrigation purposes}

Water quality plays a major role in determining the quantity and quality of the crop, especially with the deterioration of water quality in recent years due to intensive exploitation. To assess the aptitude of groundwater quality in Kerzaz and Beni Abbes for irrigation purposes, a major parameter was determined such as pH, TDS, EC, SAR MAR and PI and summarized in Table 3. All the equations used to calculate the major element for assessing groundwater quality for irrigation in Kerzaz and Beni Abbes are summarized below (Eqs. 1-4).

$$
\begin{aligned}
& \mathrm{SAR}=\mathrm{Na}^{+} / \sqrt{\frac{\mathrm{Ca}^{2+}+\mathrm{Mg}^{2+}}{2}} \\
& \% \mathrm{Na}=\left(\frac{\mathrm{Na}^{+}+\mathrm{K}^{+}}{\mathrm{Na}^{+}+\mathrm{K}^{+}+\mathrm{Ca}^{2+}+\mathrm{Mg}^{2+}}\right) \times 100 \\
& \mathrm{MAR}=100 \times\left(\frac{\mathrm{Mg}^{2+}}{\mathrm{Mg}^{2+}+\mathrm{Ca}^{2+}}\right) \\
& \mathrm{PI}=\left(\frac{\mathrm{Na}^{+}+\sqrt{\mathrm{HCO}_{3}^{-}}}{\mathrm{Ca}^{2+}+\mathrm{Mg}^{2+}+\mathrm{Na}^{2+}}\right) \times 100 .
\end{aligned}
$$

\begin{tabular}{|c|c|c|c|c|c|c|}
\hline \multirow[t]{2}{*}{ Parameter } & \multirow[t]{2}{*}{ Range } & \multirow[t]{2}{*}{ Class } & \multicolumn{2}{|l|}{ Kerzaz } & \multicolumn{2}{|l|}{ Beni Abbes } \\
\hline & & & No. of samples & $\%$ of samples & No. of samples & $\%$ of samples \\
\hline $\mathrm{pH}$ & $6.5-8.5$ & Good & $n=12$ & 100 & $n=12$ & 100 \\
\hline \multirow[t]{4}{*}{$\mathrm{EC}\left(\mu \mathrm{s} \mathrm{cm}{ }^{-1}\right)$} & $<250$ & Excellent & $n=0$ & 0 & $n=1$ & 8.33 \\
\hline & $250-750$ & Good & $n=0$ & 0 & $n=3$ & 25 \\
\hline & $750-2250$ & Doubtful & $n=7$ & 58.33 & $n=8$ & 66.66 \\
\hline & $>2250$ & Unsuitable & $n=5$ & 41.66 & $n=0$ & 0 \\
\hline \multirow[t]{4}{*}{ SAR } & $<10$ & Excellent & $n=12$ & 100 & $n=9$ & 75 \\
\hline & $10-18$ & Good & $n=0$ & 0 & $n=3$ & 25 \\
\hline & $18-26$ & Doubtful & $n=0$ & 0 & $n=0$ & 0 \\
\hline & $>26$ & Unsuitable & $n=0$ & 0 & $n=0$ & 0 \\
\hline \multirow[t]{3}{*}{ PI } & Class I (> 75\%) & Excellent & $n=0$ & 0 & $n=0$ & 0 \\
\hline & Class II (25-75\%) & Good & $n=2$ & 16.66 & $n=11$ & 91.66 \\
\hline & Class III $(<25 \%)$ & Unsuitable & $n=10$ & 83.33 & $n=1$ & 8.33 \\
\hline \multirow[t]{2}{*}{ MAR } & Class I $(<50 \%)$ & Suitable & $n=10$ & 83.33 & $n=5$ & 41.66 \\
\hline & Class II (> 50\%) & Unsuitable & $n=2$ & 16.66 & $n=7$ & 58.33 \\
\hline
\end{tabular}

Table 3 Water quality parameters for irrigation purposes 
All samples present an acceptable $\mathrm{pH}$ range (7.15-7.86) and (7.11-8.3) in Kerzaz and Beni Abbes, respectively, which were within the FAO standards (6.5-8.4) (Bashir et al. 2013; Ayers and Westcot 1985). 58.33\% of wells in Kerzaz present an electrical conductivity (EC) which is considered doubtful for irrigation; the rest were unsuitable. While in Beni Abbes $66.66 \%$ were doubtful, 25\% were good and $8.33 \%$ were excellent (the natural spring).

The sodium adsorption ratio (SAR) is a measure of the amount of sodium ( $\mathrm{Na}$ ) relative to calcium $(\mathrm{Ca})$ and magnesium $(\mathrm{Mg})$ in the water extract from saturated soil paste. The SAR values of all samples in the study area of Kerzaz were less than $10 \mu \mathrm{sm}^{-1}$ which is considered as excellent for irrigation, while in Beni Abbes only 8.33\% of samples were excellent and the remaining samples are considered doubtful to good for irrigation with $66.66 \%$ and $25 \%$, respectively.

The suitability of water for irrigation use can be determined by using the US salinity diagram (Richards 1954; USSL 1954; Al-Ahmadi 2013; Shahin Hossin et al. 2016; Bahir et al. 2019). The estimated values of EC and SAR in the groundwater samples of Kerzaz oasis fall into the field of C4S1 and C3S2 indicating very high salinity and low alkalinity which cannot be used under ordinary conditions; drainage must be applied adequately and the soil must have rapid permeability. However, $58.33 \%$ of water samples collected from Beni Abbes oasis fall into the C3S1 category indicating high salinity and low alkalinity, water can be used with rapid permeability which is the case in Beni Abbes (Hoffman et al. 1990). 25\% fall into a class which is considered medium salinity and low to medium alkalinity ( $\mathrm{C} 2 \mathrm{~S} 1$, $\mathrm{C} 2 \mathrm{~S} 2, \mathrm{C} 3 \mathrm{~S} 3$ ), and only the natural spring presents a low salinity and low alkalinity C1S1 permitting the use of water for irrigation with most crops on most soil (Fig. 2).

The permeability index is an important parameter for assessing the water quality for irrigation purposes. Following PI, water can be classified as class I ( $>75 \%$ ), class II $(25-75 \%)$ and class III $(<25 \%)$. Class I and II water are categorized as excellent and good for irrigation, respectively. Class III water is unsuitable with $25 \%$ of maximum permeability (Kumar Nag and Shreya 2014). In Kerzaz region, only $16.66 \%$ of samples were good for irrigation with PI $(25-75 \%)$ and the rest $(83.33 \%)$ were unsuitable. On the contrary, in Beni Abbes region, $91.66 \%$ of samples were good and just $8.33 \%$ of them were unsuitable for irrigation.

In groundwater, a state of equilibrium is maintained between $\mathrm{Mg}$ and $\mathrm{Ca}$. During equilibrium, more $\mathrm{Mg}^{2+}$ in groundwater adversely affects the soil quality rendering it alkaline which results in a decrease in crop yield (Kumar et al. 2007; Bashir et al. 2013; Hem 1985). According to the magnesium adsorption ratio value, water can be categorized into two classes (class I MAR $<50$ ) and class II (MAR $>50$ ). Class I water is considered suitable for irrigation, whereas water in class II is considered unsuitable.

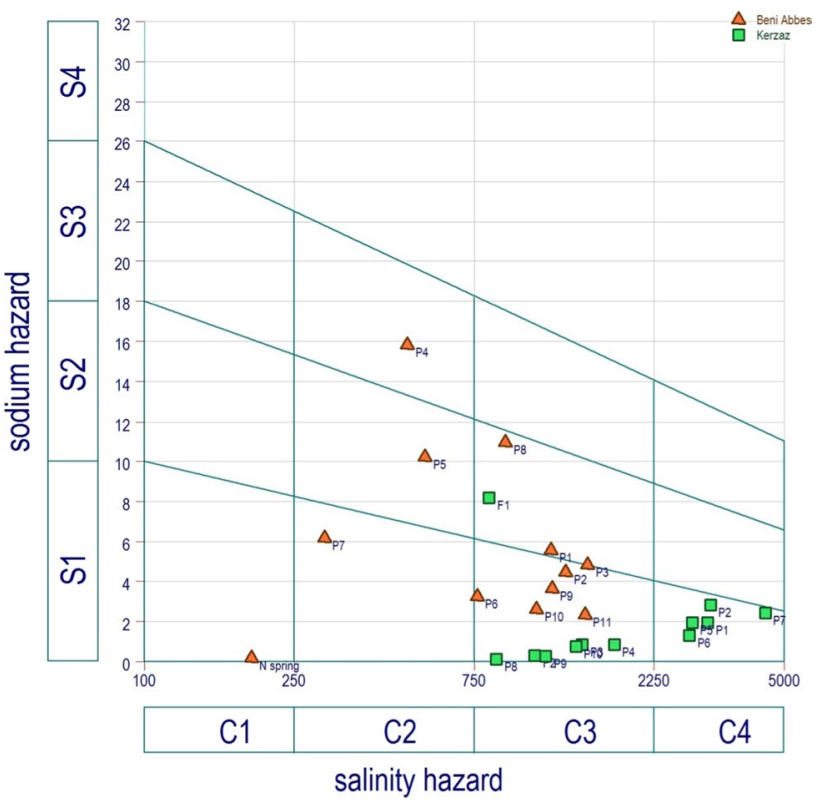

Fig. 2 Salinity versus alkalinity hazard in the US salinity diagram of groundwater samples (Kerzaz and Beni Abbes)

The MAR values of almost all samples in Kerzaz area $(83.33 \%)$ were less than 50 which is considered as suitable for irrigation; two wells (P18, P12) were unsuitable with MAR value of $60.51 \%, 50.63 \%$, respectively. In Beni Abbes, $41.66 \%$ of samples were suitable for irrigation and $58.33 \%$ were unsuitable (Table 4 ).

\section{Hydrogeochemical facies}

During their journey, the chemical composition of groundwater evolves through the crossing of different geological faults according to several modifying phenomena (Mansour 1993); according to its chemical composition, we can classify them in families using the logarithmic diagram of Piper which is composed of two triangles representing the distribution of the anions and that of the cations, respectively, and a rhombus representing a synthetic distribution of major ions. This diagram reveals similarities and differences among water samples because those with similar qualities will tend to plot together as groups (Todd 1980; Makoba and Muzuka 2019).

The representation of chemical results of waters taken from the oasis of Kerzaz and Beni Abbes on Piper diagram (Figs. 3, 4) shows that all the water samples of Kerzaz (100\%) belong to one type of $\mathrm{CaCl}$, while in Beni Abbes four types were recognized, $\mathrm{NaCl}, \mathrm{CaMgHCO}_{3}, \mathrm{CaCl}$ and mixed $\mathrm{CaCl}$ with $16.66 \%, 8.33 \%, 41.66 \%$ and $33.33 \%$, respectively. 
Table 4 Sodium adsorption ratio (SAR), electrical conductivity (EC), alkalinity and salinity hazard class

\begin{tabular}{|c|c|c|c|c|c|c|c|}
\hline \multicolumn{4}{|c|}{ Kerzaz } & \multicolumn{4}{|c|}{ Beni Abbes } \\
\hline & $\mathrm{EC}\left(\mu \mathrm{cm}^{-1}\right)$ & SAR & $\begin{array}{l}\text { Alkalinity and } \\
\text { salinity hazard } \\
\text { class }\end{array}$ & & $\mathrm{EC}\left(\mu \mathrm{s} \mathrm{cm}{ }^{-1}\right)$ & SAR & $\begin{array}{l}\text { Alkalinity and } \\
\text { salinity hazard } \\
\text { class }\end{array}$ \\
\hline $\mathrm{F} 1$ & 822 & 8.16 & $\mathrm{C} 3 \mathrm{~S} 2$ & P1 & 1205 & 5.55 & C3S1 \\
\hline P1 & 3130 & 1.94 & $\mathrm{C} 4 \mathrm{~S} 1$ & $\mathrm{P} 2$ & 1312 & 4.44 & C3S1 \\
\hline $\mathrm{F} 2$ & 1090 & 0.31 & $\mathrm{C} 3 \mathrm{~S} 1$ & P3 & 1500 & 4.82 & $\mathrm{C} 3 \mathrm{~S} 1$ \\
\hline $\mathrm{P} 2$ & 3180 & 2.84 & $\mathrm{C} 4 \mathrm{~S} 1$ & P4 & 500 & 15.74 & $\mathrm{C} 2 \mathrm{~S} 3$ \\
\hline P3 & 1450 & 0.85 & C3S1 & P5 & 556 & 10.18 & $\mathrm{C} 2 \mathrm{~S} 2$ \\
\hline P4 & 1770 & 0.87 & $\mathrm{C} 4 \mathrm{~S} 1$ & P6 & 765 & 3.22 & C3S1 \\
\hline P5 & 2850 & 1.96 & $\mathrm{C} 4 \mathrm{~S} 1$ & P7 & 300 & 6.17 & $\mathrm{C} 2 \mathrm{~S} 1$ \\
\hline P6 & 2790 & 1.33 & $\mathrm{C} 4 \mathrm{~S} 1$ & P8 & 910 & 10.93 & $\mathrm{C} 3 \mathrm{~S} 2$ \\
\hline P7 & 4450 & 2.43 & $\mathrm{C} 4 \mathrm{~S} 1$ & P9 & 1210 & 3.65 & $\mathrm{C} 3 \mathrm{~S} 1$ \\
\hline P8 & 862 & 0.12 & $\mathrm{C} 3 \mathrm{~S} 1$ & $\mathrm{P} 10$ & 1100 & 2.59 & $\mathrm{C} 3 \mathrm{~S} 1$ \\
\hline P9 & 1160 & 0.29 & $\mathrm{C} 3 \mathrm{~S} 1$ & P11 & 1475 & 2.31 & $\mathrm{C} 3 \mathrm{~S} 1$ \\
\hline P10 & 1400 & 0.75 & C3S1 & Spring & 192 & 0.17 & C1S1 \\
\hline
\end{tabular}

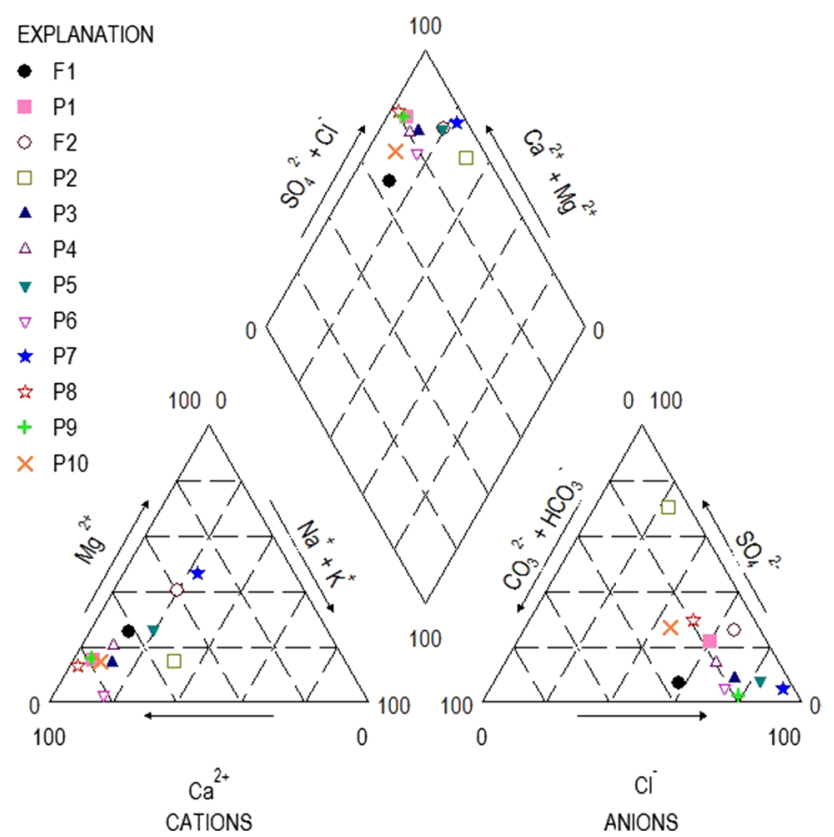

Fig. 3 Piper diagram for water samples of Kerzaz groundwater

\section{Conclusion}

The groundwater quality in Kerzaz and Beni Abbes, southwest of Algeria has been assessed for its drinking and irrigational suitability purposes. The physicochemical analyses show that $\mathrm{Cl}^{-}, \mathrm{Ca}^{2+}$ are the dominant ions in Kerzaz and $\mathrm{Cl}^{-}$in Beni Abbes. This predominance is mainly due to the leaching of Mio-Pliocene limestone and the presence of gypsum lenses and clays on the one hand and chemical processes resulting from evaporation on the other hand.

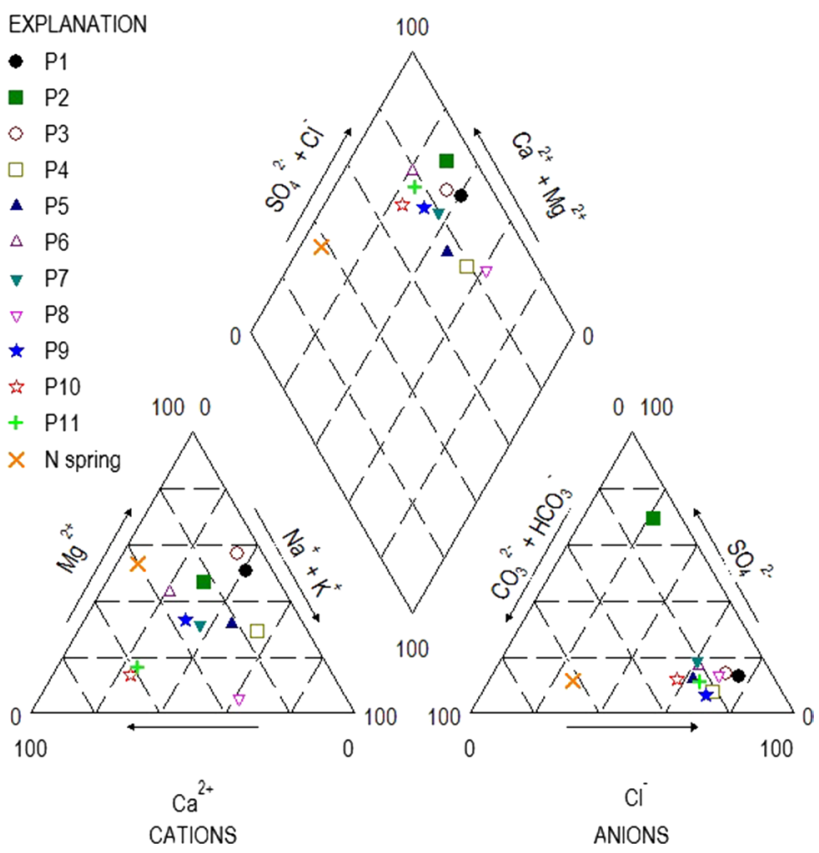

Fig. 4 Piper diagram for water samples of Beni Abbes groundwater

The groundwater in Kerzaz and Beni Abbes belongs to chlorinated and sulfated calcium and magnesium type. The $\mathrm{pH}$ values of both water samples are neutral and within the acceptable limits of drinking purposes. Most of the water samples were found to be moderate in Kerzaz and hard to very hard in Beni Abbes with more than $936 \mathrm{mg} / \mathrm{L}$ which is due to the lithology characteristics of the aquifer. In both oases, Only water samples closest to the western erg have lower conductivity and total dissolved solids values $(<100 \mathrm{mg} / \mathrm{L})$, and the rest $(25 \%)$ were to be found largely exceeded the WHO standards; this can be explained by the 
dissolution of salts contained in the quaternary formation sand, the evaporation in wells of large diameter and the rise of the groundwater table charged with salts by pumping and diffusion phenomenon. The high level of nitrates in some wells is mainly derived from various agricultural and anthropogenic activities. Only a few samples closest to the western erg in Kerzaz and Beni Abbes are within the acceptable limits for drinking purposes; the rest were to be found unsuitable.

According to $\mathrm{pH}, \mathrm{EC}, \mathrm{SAR}, \mathrm{PI}$ and MAR, the groundwater samples in Kerzaz is suitable for irrigation, especially if rapid permeability is guaranteed which is the case in Kerzaz soils, while in Beni Abbes more than half of the sampling points indicating that water quality are medium, the rest is good to excellent for irrigation purposes particularly if plants with good salt tolerance are selected.

Establishing monitoring of the quantity and quality of groundwater in the oases, the pretreatment process on sewage before adjoining Saoura wadi and construction of an underground dam perpendicular to the direction of groundwater flow is the main measurement to preserve oases and their fragile ecosystem.

Acknowledgements On behalf of all authors, I express my great thanks and gratitude to Marzougi. T Professor at Bechar University, Department of hydraulics. Thanks are extended to Ms. Nebbou professor at Bechar university, department of chemistry for providing laboratory facilities to carry out this work.

\section{Compliance with ethical standards}

Conflict of interest All the authors of this article state that there is no conflict of interest.

Open Access This article is licensed under a Creative Commons Attribution 4.0 International License, which permits use, sharing, adaptation, distribution and reproduction in any medium or format, as long as you give appropriate credit to the original author(s) and the source, provide a link to the Creative Commons licence, and indicate if changes were made. The images or other third party material in this article are included in the article's Creative Commons licence, unless indicated otherwise in a credit line to the material. If material is not included in the article's Creative Commons licence and your intended use is not permitted by statutory regulation or exceeds the permitted use, you will need to obtain permission directly from the copyright holder. To view a copy of this licence, visit http://creativecommons.org/licenses/by/4.0/.

\section{References}

Al-Ahmadi ME (2013) Hydrochemical characterization of groundwater in wadi Sayyah, Western Saudi Arabia. Appl Water Sci 3:721-732

APHA (1998) Standard methods for the examination of water and wastewater analysis, 20th edn. American Public Health Association, Washington

Amadou H, Laouali M, Manzola A (2014) Caractérisation hydro chimique des Eaux souterraines de la region de Tahoua, Niger. J Appl Biosci 80:7161-7172
Ayers RS, Westcot DW (1985) Water quality for agriculture. FAO irrigation and drainage paper no (29), Rev. (1), U.N. Food and Agriculture Organization, Rome

Bahir M, Ouazar D, Ouhamdouch S (2019) Hydrogeochemical mechanisms and recharge mode of the aquifers under semiarid climate from Morocco. Appl Water Sci 9:103. https://doi.org/10.1007/ s13201-019-0988-7

Bashir E, Naseem S, Hanif H, Pirzada T (2013) Geochemical study of groundwater of Uthal and Bela areas, Balochistan and its appraisal for drinking and irrigation water quality. Int $\mathbf{J}$ Agric Environ 2:1-13

Chattopadhyay S, Asa RL, Sangeetha PV (2005) Water quality variations as linked to land use pattern: a case study in Chalakudy river Basin, Kerala. Curr Sci 89(12):2163-2169

Dubief J (1955) Essai sur l'hydrologie superficielle au Sahara. Institut de météorologie et de physique du globe de l'Algérie Service des études scientifiques. Banlieu d'alger, Algeria pp 108-163.

Hadidi A, Remini B, Habi M (2018) Evolution of capture technologies of water in the oases: Moghrar, Tiout and Boussemghoun, Algeria. J Water Land Dev 37:57-63

Hem JD (1985) Study and interpretation of the chemical characteristics of natural water, 3rd edn. Scientific Publishers, Jodhpur, p 2254

Hoffman GJ, Rhoades JD, Letey J, Sheng F (1990) Salinity management. In: Hoffman GJ, Howell TA, Solomon KH (eds) Management of farm irrigation systems. ASAE Monograph, Michigan, pp 664-715

Kabour A, Mekkaoui A, Chebbah L (2016) The dam of Djorf Torba (Bechar) under constraints of climate, environment and management, SW Algeria. Int J Environ Glob Clim Change 03:23-32

Krishna Kumar S, Rammohan V, Dajkumar Sahayam J, Jeevanandam M (2009) Assessment of groundwater quality and hydrogeochemistry of Manimuktha River basin, Tamil Nadu, India. Environ Monit Assess 159:341-351

Kumar M, Kumari K, Ramanathan AL, Saxena R (2007) A comparative evaluation of groundwater suitability for irrigation and drinking purposes in two intensively cultivated districts of Punjab, India. Environ Geol 53:553-574

Kumar Nag S, Shreya D (2014) Quality assessment of groundwater with special emphasis on irrigation and domestic suitability in Suri I \& II blocks, Birbhum district, West Bengal, India. Am J Water Res 2(4):81-98. https://doi.org/10.12691/ajwr-2-4-2

Lachache S, Nabou M, Merzouguui T, Amroune A (2018) Hydrochemistry and origin of principal major elements in the groundwater of the Béchar-Kénadsa basin in arid zone, south-west of Algeria. J Water Land Dev 36:77-87

Makoba E, Muzuka ANN (2019) Water quality and hydrogeochemical characteristics of groundwater around Mt. Meru, Northern Tanzania. Appl Water Sci 9:120. https://doi.org/10.1007/s1320 1-019-0955-3

Mansour H (1993) Les isotopes dans l'eau du Sahara Nord Occidental Algérien (Grand Erg Occidental-Hammada du Guir). 2éme journées de géologie appliquées, Sfax, pp 88-111

Margat J. 1990. Les eaux souterraines dans le monde (Groundwater in the world). Rapport BRGM R 31 780. Orleans France p 38

Merzougui T (2011) Caractérisation hydrogéologique et modélisation d'un aquifère alluvial en zone hyper aride : cas de la nappe de la palmeraie de Beni Abbes, vallée de la saoura, sud ouest algérien, University of Tlemcen

Oga MS, Gnamba FM, Lasm T, Gnangne T, Baka D, Soro N, Biemi J (2010) Caractérisation physico-chimique des eaux souterraines de Katiola, Centre-Nord De La Cote D'ivoire. Revue des sciences de la vie et de la terre 10:8-25

Remini B (2016) The role of the gallery in the functioning of the foggara. J Water Land Dev 29:49-57. https://doi.org/10.1515/ jwld-2016-0011 
Rezzoug C, Remini B, Hamoudi S (2017) La connaissance de l'irrigation traditionnelle dans l'oasis de keerzaz dans le sudouest de l'algerie: héritage et développement. J Fundam Appl Sci 9:261-273

Rice EW, Baird RB, Eaton AD (2017) Standard methods for the examination of water and wastewater, 23rd edn. American public health association American water works association water environment federation, Washington

Richards LA (1954) Diagnosis and improvement of saline and alkali soils. Department of Agricultural Hand-book, Washington

Rodier J, Legube B, Merlet N, Brunet R (2009) L'analyse de l'eau: Eaux naturelles, eaux résiduaires, eau de mer. France, Paris

Sayad L, Djabri L, Bouhsina S, Bertrand C, Hani A, Chaffai H (2017) Hydrochemical study of Drean-Annaba aquifer system, NE Algeria. J Water Land Dev 34:259-263

Shahin Hossin MD, Abdul Matin MD, Mohammad KI, Mustafizur Rahman MD, Morsheda AM, Sagirul Islam Majumder MD (2016) Water quality assessment of deep aquifer for drinking and irrigation purposes in selected coastal region of Bangladesh. A J Agric Sci 3(6):85-91
Todd DK (1980) Ground water hydrology, 2nd edn. Wiley, New York U.S. Salinity Lab (1954) Saline and alkali soils-diagnosis and improvement of U.S. Salinity Laboratory. Agriculture hand book No.60, Washington

Weast RC (1968) Handbook of chemistry and physics, 49th edn. Cleveland, Ohio

World Health Organization (WHO) (2008) Guidelines for drinking water quality. Third edition, incorporating the first and second addenda, vol. 1, Recommendations. WHO, Geneva

World Health Organization (WHO) (2011) Guidelines for drinking water quality, 4 th edn

Publisher's Note Springer Nature remains neutral with regard to jurisdictional claims in published maps and institutional affiliations. 